Doctor of Economics, Professor Head of the Department of innovative entrepreneurship management and international economic relations

Yana Maksymenko

Ph.D in Economics

Associate Professor, Professor of the Department of Economics

Kateryna Sokol

Ph.D in Economics

Associate Professor of the Department of Economic Cybernetics and Marketing Management

National Technical University «Kharkiv Polytechnic Institute»

(Kharkiv, Ukraine)

\title{
MARKETING PREREQUISITES FOR ENTERING THE ENTERPRISE IN THE INTERNATIONAL MARKET OF INFORMATION TECHNOLOGIES
}

It is substantiated that for a successful entry into the world market, an information enterprise needs to solve a number of important issues: to determine the desired and most attractive market segment that corresponds to the material capabilities of the enterprise; risks; choose the time to market; assess the scale of market entry; substantiate the way (form) of entering the international market. It is recommended to build a future strategy of the information enterprise in the international market using the concept of three horizons: the first horizon reflects the work of the enterprise to further improve the existing information product; the second horizon reflects the work of the enterprise to find new sources of profit; the third horizon reflects the capabilities of the enterprise, given the availability of the required amount of material and intellectual resources, access to international markets with a progressive information product developed on the basis of the blockchain.

Key words: information technology, international market, marketing strategies, development horizons, risks

\section{DOI: 10.15276/mdt.4.3.2020.2}

Statement of the problem in general form and it's connection with important scientific or practical tasks. One of the most important strategic goals of Ukrainian information enterprises is to enter the international market. At the same time, it should be noted that this strategic task presupposes continuous work, the results of which are intended to ensure the readiness of the enterprise to sell the necessary information technologies abroad in a certain segment of the international market (country, region), taking into account the original characteristics of this market segment and the level of development of its consumers.

It should be understood that the activity of an enterprise in the foreign market is distinguished by a significantly higher level of risk (in comparison with the national market) due to the existing differences in economic, political, cultural, legal conditions, as well as a 
higher state of competition, requirements for the quality of a technological product, its packaging, labeling, service, etc. You should also be prepared for a higher level of international marketing research spending.

The international information technology market is currently characterized by a high level of competition both between individual enterprises and between individual countries, high dynamics of development and a high degree of science intensity and innovation, consumer behavior patterns, as well as the specifics of products and services offered in this market. In this regard, companies operating in the global information technology market are forced to constantly improve their products, expand the range and quality of services, optimize production and management processes, as well as use all available resources and tools that allow them to resist constantly growing competition. The leading role in this process belongs to the strategy of the company, which not only determines the priority strategic goals of the company to enter the world information technology market, but also sets the rules for making decisions in the event of changes in external economic conditions that ensure the required level of achievement of these goals, and one of such tools is an international marketing that offers a set of technologies that enable companies to operate successfully in this modern global competitive market. So, the issues related to the formation of marketing strategies for the entry of domestic IT companies into the international information technology market are currently very important.

All these features determine the need and relevance of the scientific study of the international strategy of information enterprises, detailed and scientifically based planning of production and commercial activities and the implementation of marketing research on the international market.

Analysis of the latest research and publications, which initiated the solution of this problem and on which the author relies. The work of many domestic scientists is devoted to the study of the theoretical and methodological provisions of international marketing, strategic marketing planning, marketing strategies and the processes of their formation and practical implementation, as well as issues on the formation of marketing strategies for Ukrainian enterprises to enter foreign markets. In the work of S.V. Tyutyunnikova "Theoretical foundations of the formation of the marketing strategy of domestic enterprises when entering the foreign market" defines the principles of the marketing strategy of Ukrainian enterprises in the foreign market and considers the effectiveness of using an integrated approach to its formation [1]. In the article by T.V. Spivakovskaya. "Formation of international marketing strategy" investigated the process of international marketing of an enterprise and proposed a structural-logical scheme for making strategic decisions on the choice of foreign markets and segments [2]. In articles Ivashkiv I.R. "Analysis of the main stages of decision-making on the entry of the organization into foreign markets" and Semenchuk TB "Stages of an enterprise entering international markets in the context of globalization of the world economy", the main stages of an enterprise entering international markets were studied as a set of strategic and organizational and economic decisions aimed at achieving a stable competitive position of an enterprise, methods for assessing the attractiveness of international markets in a globalized world economy processes, the stages of an enterprise's entry into international markets are determined in order to develop effective market strategies [3, 4]. And in the works of Mushtai V.A. "Substantiation of the marketing capabilities of the enterprise and analysis of the risks of its activities" and Shapoval A.V. "Marketing tools for an enterprise to enter new foreign markets" assessed the feasibility of an enterprise to enter a foreign target market, taking into account potential risks, and investigated marketing tools for entering new foreign markets [5, 6]. The works of P. Ilchuk "Study of the influence of internal factors on the formation of a marketing strategy for the internationalization of enterprises" and Blagun I.S. "External factors 
of influence on the formation of the marketing strategy of internationalization of enterprises" is devoted to the study of external and internal factors influencing the formation of the marketing strategy of internationalization [7, 8], and the work of Shimanskaya L.M. "Assessment of the impact of characteristics of the external market on the competitiveness of the company's products" is devoted to the methodology for assessing the barriers that arise when an enterprise enters new international markets [9]. In the article by V.V. Zinovchuk. "Development and implementation of an international marketing strategy for a forestry enterprise" considered strategic options for the entry of forestry enterprises to foreign markets and proposed an algorithm for the development and implementation of an international marketing strategy [10], and the work of N.V. Skidonenko. is devoted to the strategy of airlines entering foreign markets [11].

Highlighting the previously unresolved parts of the general problem to which the article is devoted. At the same time, a detailed analysis of the above and other [14-26] scientific studies allow us to conclude that many problematic issues on the formation of marketing strategies for companies to enter foreign markets have not been studied enough. In particular, there is ambiguity in the interpretation of marketing strategies in general and marketing strategies for entering international markets; there is no unified systematic methodological approach to their formation; issues directly related to the formation of marketing strategies for companies to enter the international information technology market are fully covered. All this, taking into account the importance of the development of the IT-industry for the country's economy and the entry of domestic IT-enterprises into the international information technology market, emphasizes the importance and relevance of the topic of the study.

Formulation of the purpose of the article (statement of the problem). The purpose of the study is to determine the features of the formation of models for the entry of Ukrainian enterprises to the international market and to substantiate methodological recommendations for developing a marketing strategy for an IT company to enter the international information technology market.

Statement of the main material of the research with full justification of the

scientific results obtained. In the context of the development of the processes of globalization of national economies, an increasing number of enterprises want to develop international (external) markets in order to strengthen their leading positions in their field of activity. The entry of the information business into international markets allows attracting new consumers, reducing the risk of losses, significantly increasing the level of competitiveness of enterprises and increasing the level of their capitalization. Entry of enterprises to international markets is an important and responsible strategic decision. Several important reasons affect the adoption of such a decision, among which the following should be noted:

- the desire of the enterprise to increase the volume of profit and ensure the growth of its business activity in the conditions of the national market saturated with similar goods and technologies;

- the desire to increase the level of competitiveness of their products through the use of intellectual competencies (patents, unique technologies, know-how, a new level of relationships with consumers, etc.);

- to minimize commercial risks and possible losses during the financial crisis by introducing enterprises to international markets.

Due to the effective solution of the assigned tasks, there are real opportunities for the growth of the level of capitalization of the business of enterprises and its resistance to changing market factors (actions of competitors, legislative changes, etc.). 
The decision to organize a business in another country is preceded by an analysis of the current situation and development prospects of the company, which is expressed in the following questions:

- determination of the desired and most attractive segment of the international information market, which corresponds to the material capabilities of the enterprise, the possibility of expansion and provides acceptable commercial risks;

- the time to enter the market, determines the presence of the most favorable opportunities for the enterprise for the development of a new segment of the information market, and also provides real opportunities for successful competition;

- the scale of entering the market, which largely depends on the availability of material and intellectual capabilities of the enterprise: an aggressive market strategy (mass market capture) or an evolutionary market strategy (a gradual increase in the market share of the enterprise);

- to determine the form (path) of entering the market, i.e. how an enterprise can achieve the desired goal: create a joint venture, organize one of the forms of exporting its products to the foreign market, acquire a franchise from one of the companies well-known in the foreign market, etc.

In Table 1, we present the main tasks of an enterprise striving to enter the world information technology market, as well as options for their solution and recommendations for the success of this process.

Table 1 - Tasks of the enterprise to enter the world market and options for their solution

\begin{tabular}{|c|c|c|}
\hline Enterprise objectives & Solution option & Recommendations \\
\hline $\begin{array}{l}\text { Choosing a segment } \\
\text { of the international } \\
\text { market }\end{array}$ & $\begin{array}{l}\text { Segment of the international } \\
\text { market that presupposes a } \\
\text { sustainable competitive } \\
\text { advantage }\end{array}$ & $\begin{array}{l}\text { The capabilities (resources) of the enterprise } \\
\text { must meet the marketing needs of the } \\
\text { segment }\end{array}$ \\
\hline \multirow[t]{3}{*}{$\begin{array}{l}\text { Time to market } \\
\text { (depends on the state } \\
\text { of the selected market } \\
\text { segment) }\end{array}$} & $\begin{array}{l}\text { New market (segment) and } \\
\text { new } \\
\text { technologies }\end{array}$ & $\begin{array}{l}\text { It is recommended to carry out preliminary } \\
\text { work to prepare the market for the new } \\
\text { information technology. There are } \\
\text { opportunities to get profitable channels for } \\
\text { technology implementation. It is difficult to } \\
\text { gain a dominant role in the market. }\end{array}$ \\
\hline & $\begin{array}{l}\text { New technologies in a } \\
\text { traditional but emerging } \\
\text { market }\end{array}$ & $\begin{array}{l}\text { Evolutionary market development is } \\
\text { recommended (by stages of the technology } \\
\text { life cycle). Leading the market is hard for } \\
\text { innovators }\end{array}$ \\
\hline & $\begin{array}{l}\text { Traditional technologies in } \\
\text { the traditional market }\end{array}$ & $\begin{array}{l}\text { Very quick market conquest is } \\
\text { recommended. Significant material } \\
\text { opportunities are required }\end{array}$ \\
\hline \multirow[t]{2}{*}{$\begin{array}{l}\text { Form (path) of } \\
\text { entering the market }\end{array}$} & $\begin{array}{l}\text { Joint venture (risk of high } \\
\text { costs and conflicts with } \\
\text { partners) }\end{array}$ & $\begin{array}{l}\text { Allows you to gain access to parterre } \\
\text { technologies, gain experience from it. } \\
\text { Doesn't allow you to get full control over the } \\
\text { market }\end{array}$ \\
\hline & $\begin{array}{l}\text { Export (direct, indirect, } \\
\text { joint) }\end{array}$ & $\begin{array}{l}\text { Lack of high costs when entering the } \\
\text { international market. Exports can be } \\
\text { unprofitable with significant customs duties }\end{array}$ \\
\hline
\end{tabular}


Continue tabl. 1

\begin{tabular}{|l|l|l|}
\hline & $\begin{array}{l}\text { Franchising - transfer to an } \\
\text { intermediary of a franchise } \\
\text { the right to conduct business } \\
\text { under its own trademark }\end{array}$ & $\begin{array}{l}\text { Lack of significant costs when entering the } \\
\text { international market. Quality control of } \\
\text { manufactured products becomes more } \\
\text { complicated }\end{array}$ \\
\hline $\begin{array}{l}\text { Licensing - transfer of the } \\
\text { right to use technologies, } \\
\text { patents, etc. to a foreign } \\
\text { company }\end{array}$ & $\begin{array}{l}\text { Provides a low level of costs for } \\
\text { organization and control, the ability to set } \\
\text { your own strict conditions for conducting } \\
\text { business. Difficulties arise in control, the } \\
\text { uniqueness of the technology is lost }\end{array}$ \\
\hline Mergers / acquisitions & $\begin{array}{l}\text { Due to the use of the resources of the } \\
\text { absorbed enterprise, a quick entry into the } \\
\text { international market is carried out }\end{array}$ \\
\hline
\end{tabular}

Source: generated by the authors

It is recommended to build the future strategy of the information enterprise in the international market using the concept of three horizons (Fig. 1) [17-19].

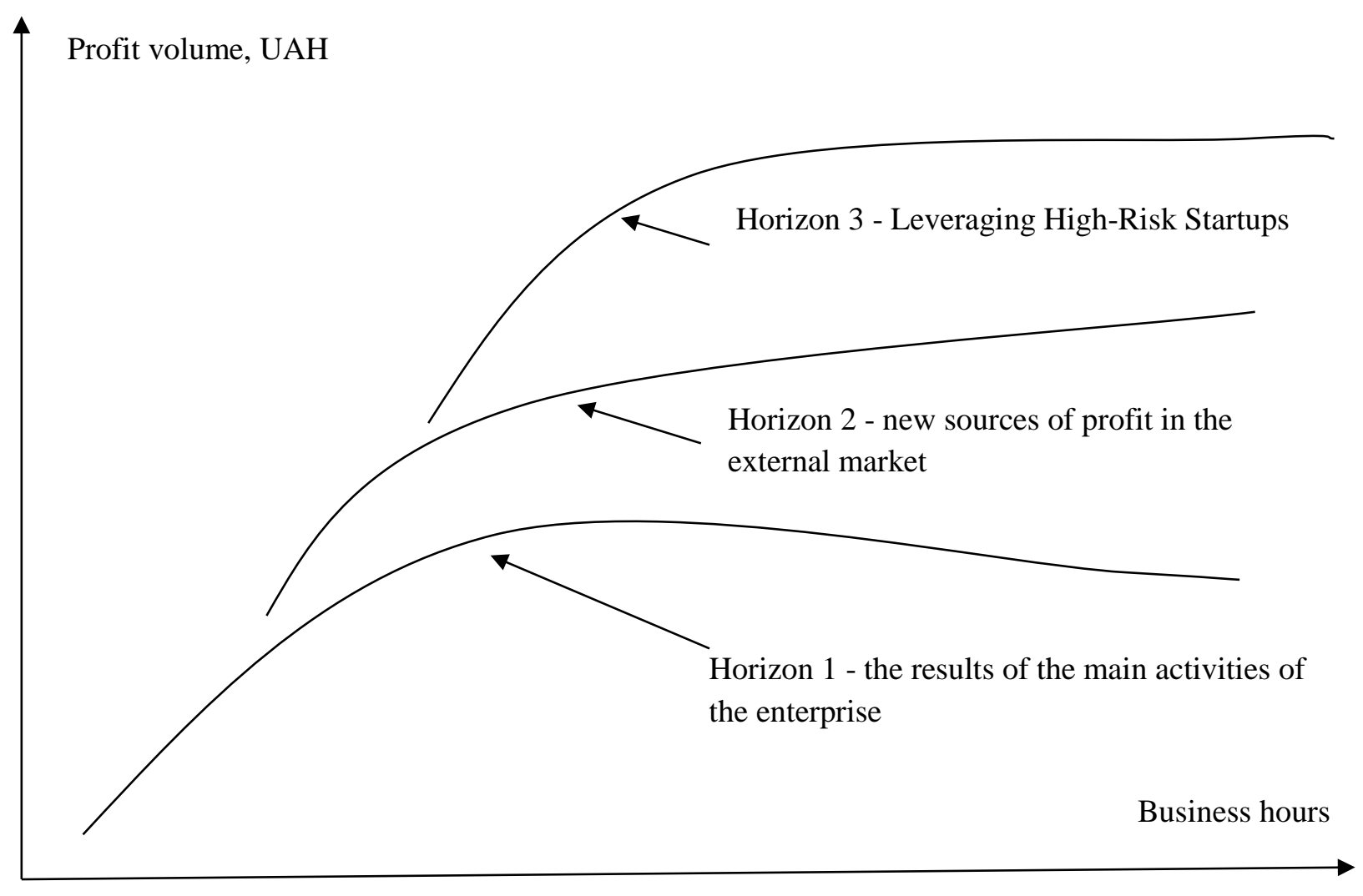

Figure 1 - Strategies of three horizons of the enterprise in the international market Source: built by the authors using [16]

The first horizon reflects the work of the company to further improve the existing information product, which allows the company to maintain and maintain its market share and maintain a certain stability of work, as well as ensure consumer loyalty to its brand. At the same time, it is recommended to take into account to a certain extent the specifics of the consumption of an information product in different countries (market segments). 
The second horizon reflects the work of the enterprise to find new sources of profit. In line with the approach proposed by Acer founder Stan Shih in 1992, the greatest added value to information enterprises comes from patents and technology, and the enterprise brand. Taking into account the specifics of ICL Service, it is recommended that information enterprises try to develop new information areas - for example, security, monitoring, video surveillance software - which may be potential areas of activity in the international market [17].

The third horizon reflects the capabilities of the enterprise, taking into account the availability of the required amount of material and intellectual resources, entering international markets with a progressive information product developed on the basis of the blockchain. For example, it can be smart contracts [18]. The renewed brand and positive reputation of the company will help it to promote information technologies in the international market and get a significant increase in profits. Note that in this strategic horizon of the information enterprise there are significant commercial risks.

We will assume that the formation of appropriate marketing strategies on each of the three horizons necessarily provides for the stage of analysis and assessment of the corresponding marketing strategic alternatives in order to select for the further implementation of such marketing strategies that best match the marketing goals and capabilities of the enterprise on each of the horizons, its strategic business -units and functional marketing division in target segments of the international market within the current and future business portfolio of the information enterprise.

A special role in the formation of a marketing strategy for an information enterprise to enter the international market should be assigned to the choice of marketing competitive strategies, which should be considered from the point of view of creating competitive advantages and ensuring the competitiveness of the enterprise, as well as from the point of view of its competitive behavior in order to achieve and maintain stable competitive positions. enterprises on the world market. As competitive strategic alternatives, it is advisable to consider classical competitive strategies according to the criteria for obtaining a competitive advantage (price leadership strategy, differentiation strategy, focusing strategy and optimal prices) and according to the criteria of market position (market leader strategy, Challenger strategy (candidate for leadership), follower strategy, nichera strategy, etc.) [14, 15].

Considering that in modern high-tech markets those enterprises that have formed their competitive advantages on the basis of advanced innovative technology, low costs in their industry and better adaptation to market conditions and needs are successful, as well as the fact that in these markets it is the information technology that lies at the heart of the creation of products or the provision of services becomes one of the main sources and tools on the basis of which competitive advantages are formed, the information technology factor should be the basis for the formation of appropriate competitive strategies of an enterprise when entering the international high-tech market. At the same time, the process of obtaining a competitive advantage in a high-tech market should be described by the following sequential chain: innovative technology - high consumer value - effective positioning in the target segment of the foreign market - differentiated offer - to meet the specific needs of consumers [20].

So, to the competitive strategic alternatives of an information enterprise, as an enterprise of a high-tech industry according to the criterion of creating competitive advantages, it is proposed to include the corresponding technological strategies characterizing the level of technology development: the strategy of early technological leadership, the strategy of late technological leadership and the strategy of technological sequence.

Potential sources of competitive advantages of information enterprises in the modern high-tech market, which is the global information technology market, are proposed to include: 
- possession of a unique technology (the third horizon of the enterprise), which underlies the creation of products or the provision of services,

- innovativeness of the offered products or services;

- providing the opportunity to improve the quality characteristics of existing products or services that are very important to consumers;

- continuous and timely improvement and updating of the range of products or services, taking into account the requirements of the modern international market.

Achieving success in competition in today's dynamic high-tech markets is a consequence of the constant search for new, non-traditional sources of competitive advantages and the use of new integrated approaches to managing the competitive advantages of an enterprise. In the context of the international information technology market, the implementation of classical competitive strategies alone is not enough to achieve competitive advantages of an enterprise. Therefore, it is expedient, in our opinion, to use modern hybrid (combined) competitive strategies, which, in contrast to classical competitive strategies, combine low-cost marketing strategies and information product differentiation strategies based on creating high consumer value. The success of hybrid competitive strategies and a simultaneous decrease in the effectiveness of classical competitive strategies in the international information technology market is due to the fact that competitive advantages are inherently short-lived, supply in the market exceeds demand, there is a steady tendency to evade competition or change its form and is gaining its development the concept of the uniqueness of the company and the consumer value of its products [21-23]. In conditions of high rates of development of the international market of information technologies and copying of information technologies, direct competition between information enterprises is too expensive and destructive for the enterprise. Therefore, modern competitive strategies are often directed towards the formation of future progressive segments of information markets, in which it would be possible to evade competition.

Considering the concepts of modern marketing competitive strategies, one should also take into account the innovative concept of intellectual leadership by G. Hamel and K. Prahalad, according to which marketing efforts should not be limited to meeting existing needs, but should be aimed at offering such products or services that consumers are still talking about. don't know. According to G. Hamel and K. Prahalad, the main reason for the success of leading enterprises in the global information technology market is that they can create new products, services and even entire industries with the help of intellectual superiority. Thus, these enterprises create a new market space in which they can dominate competitors, which provides them with the opportunity to "penetrate" the markets of the future. To achieve this goal, the information company must also independently form the needs of its potential consumers, thus creating new markets for itself $[12,15,24-26]$.

\section{Conclusions from this research and prospects for further developments in this}

area. The study of marketing competitive strategies conducted by the authors allows us to conclude that in the modern world information technology market, only those information enterprises can successfully compete that will offer consumers truly unique innovative information products and information services or create new needs among consumers, thus creating new market segments (market niches). The final main result of the formation of a marketing strategy for an information enterprise to enter the foreign market is the creation of an international marketing complex of the enterprise adequate to the market environment and the characteristics of the target segments of the foreign market. The main elements of this complex correspond to separate functional marketing strategies, which are the main marketing tools of the company and its strategic business units in the target segments of the external market to achieve the strategic marketing goals of the enterprise. 
Thus, the proposed approach to the formation of a marketing strategy for an information enterprise to enter the international information technology market is a methodological tool that allows you to form a marketing strategy for an information enterprise, the implementation of which will help achieve its strategic marketing goals when entering the international information technology market.

The use of modern marketing strategies by Ukrainian information enterprises planning to enter the international information technology market allows obtaining certain competitive advantages, and the key to the successful implementation of their plans to enter this market is precisely the presence of a well-founded marketing strategy for entering the international information technology market, which plays a significant role in this process.

1. Tyutyunnikova S.V., Kot O.V., Levin R.V. (2010) Teoretichni osnovi formuvannya marketingovoyi strategiyi vitchiznyanih pidpriemstv u razi vihodu na zovnishniy rinok [Theoretical bases of formation of marketing strategy of domestic enterprises in case of entering the foreign market]. Economic strategy and prospects of trade and services development, no. 2., pp. 393-399.

2. Spivakovska T.V. (2013) Formuvannya mizhnarodnoyi marketingovoyi strategiyi [Formation of international marketing strategy]. Effective economy, no 2. Available at: http://www.economy. nayka.com.ua/?Op=1\&z=1845 (accessed 10 January 2020).

3. Ivashkiv I. (2013) Analiz osnovnih etapiv z priynyattya rishen po vihodu organizatsiyi na zovnishni rinki [Analysis of the main stages of decision-making on the organizations entry into foreign markets]. Galician Economic Bulletin, no. 4 (43), pp. 222-228.

4. Semenchuk T.B., Poberezhna L.V. Etapi vihodu pidpriemstva na mizhnarodni rinki v umovah globalizatsiyi svitovogo gospodarstva [Stages of enterprise entry into international markets in the context of globalization of the world economy]. Water transport, no. 3, pp. 153-157.

5. Mushtay V.A. (2013) Obgruntuvannya marketingovih mozhlivostey pidpriemstva ta analiz rizikiv yogo diyalnosti [Substantiation of marketing opportunities of the enterprise and analysis of risks of its activity]. Visnyk of Sumy National Agrarian University. Finance and Credit, no. 1, pp. 154-162.

6. Shapoval O.V., Konnova L.O., Kirichenko T.S. (2014) Marketingovi instrumenti vihodu pidpriemstva na novi zarubizhni rinki [Marketing tools of enterprise entry into new foreign markets]. Scientific Bulletin of the National University of Life and Environmental Sciences of Ukraine. Series: Economics, agricultural management, business, no. 200 (1), pp. 341-346.

7. Ilchuk P.G. (2013) Doslidzhennya vplivu faktoriv vnutrishnogo harakteru na formuvannya marketingovoyi strategiyi internatsionalizatsiyi pidpriemstv [Research of influence of factors of internal character on formation of marketing strategy of internationalization of enterprises]. Scientific herald of Uzhhorod University: Series: Economy, no. 4 (41), pp. 181-187.

8. Blagun I.S., Ilchuk P.G. (2013) Zovnishni faktori vplivu na formuvannya marketingovoyi strategiyi internatsionalizatsiyi pidpriemstv [External factors influencing the formation of marketing strategy of internationalization of enterprises]. Economic Journal-XXI, no. 11-12 (1), pp. 46-49.

9. Shimanska L.M. (2013) Otsinka vplivu harakteristik zovnishnogo rinku na konkurentospromozhnist produktsiyi pidpriemstva [Development and implementation of the strategy of international marketing of forestry enterprises]. Science and economy, vol. 2, no. 4, pp. 338-342.

10. Zinovchuk V.V., Osipchuk A.S. (2014) Rozrobka ta implementatsiya strategiyi mizhnarodnogo marketingu lisogospodarskogo pidpriemstva [Development and implementation of the strategy of international marketing of forestry enterprises. Visnyk of Zhytomyr National Agroecological University, no 1-2 (2), pp. 94-103.

11. Skidonenko N.V. (2013) Strategiya vihodu aviakompaniy na zovnishni rinki turistichnih poslug [Strategy of airlines entering foreign markets of tourist services]. Collection of scientific works of the State Economic and Technological University of Transport. Ser.: Ekonomika iupravlinnya, no. 2, pp 174-179.

12. Demkiv Ya.V. (2011) Strategiya vhodzhennya na rinok yak vid marketingovoyi strategiyi [Market entry strategy as a type of marketing strategy]. Proceedings of the Modern problems of economics and 
management (Ukraine, Lviv, April 15-19, 2011) Lviv: Lvivska politehnika, pp. 44-45.

13. Kudenko N.V. (2003) Marketingove strategichne planuvannya [Marketing strategic planning]. Avtoref. Dis. Dokt. Ekon. Nauk. Kyiv: Natsionalnyi ekonomichnyi universytet.

14. Demkiv Ya.V. (2008) Formuvannya konkurentnoyi strategiyi na rinkah visokotehnologichnih tovariv [Formation of competitive strategy in the markets of high-tech goods]. Bulletin of the National University "Lviv Polytechnic", no. 628, pp. 470-476.

15. Lyashenko V.I., Lyashenko S.V. Suchasni tendentsiyi rozvitku strategichnogo marketingu [Modern tendencies of strategic marketing development]. Available at: http://dere.com.ua/library/reshta/strateg marketing.shtml (accessed 10 January 20120).

16. Baghai M., Coley S., White D. (2000) The alchemy of growth: Practical insights for building the enduring enterprise. Da Capo Press.

17. Shih S.(1992) Empowering technology - making your life easier. Acer's Report. Acer's, New Taipei. 18. Podkovyrov P.A. (2018) Stratehyy vykhoda kompanyy na zarubezhnye rynky [Strategies for companies to enter foreign markets]. Science, Technology and Education, no. 6 (47). Available at: https://cyberleninka.ru/article/n/strategii-vyhoda-kompaniy-na-zarubezhnye-rynki. (accessed 15 January 2020).

19. Volodin Y.V., Podkovyrov P.A. (2018) Stratehyy vykhoda na mezhdunarodnye rynky: sravnytel'nyy analyz nemetskykh y rossyyskykh kompanyy [Strategies for entering international markets: a comparative analysis of German and Russian companies]. CPPM, no. 4 (107). Available at: https://cyberleninka.ru/article/n/strategii-vyhoda-na-mezhdunarodnye-rynki-sravnitelnyy-analiznemetskih-i-rossiiskih-kompanii. (accessed 5 January 2020).

20. Sokol K.M. (2014) Formuvannya marketynhovoyi stratehiyi vykhodu IT-kompaniyi na svitovyy rynok informatsiynykh tekhnolohiy [Smolovik RF Fundamentals of high technology marketing]. Foreign trade: economics, finance, law], no. 5-6, pp.76-77.

21. Compliance program of an industrial enterprise. Tutorial. (2019) Kharkov-Miskolc: NTU "KhPI", $689 \mathrm{p}$.

22. Grabchenko A.I., Smolovik R.F. (1999) Fundamentals of high technology marketing. Kharkiv: KhGPU, 242 p.

23. Starostina A.O. (2009) Marketynh: teoriya, svitovyy dosvid, ukrayinska praktyka: pidruch [Marketing: theory, world experience, Ukrainian practice: under the leadership]. K.: Znannya, 1070 p.

24. Goncharova N.P., Yakovlev A.I. (1998) Marketynh ynnovatsyonnoho protsessa [Marketing of the innovation process]. K.: VIRA-R, $267 \mathrm{p}$.

25. Kocziszky György, Szakaly D., Somosi Veres M. (2012) Technology transfer. Kharkiv-Miskolc: $\mathrm{NTU}$ «KhPI», $668 \mathrm{p}$.

26. Goncharova N.P., Yakovlev A.I. (1989) Novye tekhnolohycheskye systemy: kachestvo, potrebnost, éffektyvnost. [New technological systems: quality, need, efficiency]. K.: Naukova dumka, 176 p.

П.Г. Перерва, д-р екон.наук, професор, завідувач кафедри менеджменту інновачійного підприсмництва та міжснародних економічних відносин, Національний технічний університет «Харківський політехнічний інститут» (Харків, Украйна).

Я.А. Максименко, канд. екон.наук, дочент, професор кафедри економічної кібернетики та маркетингового загальної економічної теорії, Національний технічний університет «Харківський політехнічний інститут» (Харків, Украӥна).

К.М. Сокол, канд. екон.наук, доцент, доцент кафедри економічної кібернетики та маркетингового менеджменту, Національний технічний університет «Харківський політехнічний інститут» (Харків, Україна).

\section{Маркетингові передумови виходу підприємства на міжнародний ринок інформаційних технологій.}

Обгрунтовано, що для успішного виходу на світовий ринок інформаційному підприємству необхідно вирішити ряд важсливих питань: визначити бажаний $і$ найбільш привабливий сегмент ринку, який відповідає матеріальним можливостям підприємства; ризики; вибрати час виходу на ринок; оцінити масштаби виходу на ринок; обтрунтувати шлях (форму) 
виходу на міжнародний ринок. Рекомендовано будувати майбутню стратегію роботи інформаційного підприємства на міжнародному ринку з використанням концепції трьох горизонтів: перший горизонт відображає роботу підприємства щодо подальшого вдосконалення існуючого інформачійного продукту; другий горизонт відображає роботу підприємства з пошуку нових джерел прибутку; третій горизонт відображає можливості підприємства, враховуючи наявність необхідної кількості матеріальних та інтелектуальних ресурсів, виходу на міжнародні ринки з прогресивним інформачійним продуктом, розробленим на базі блокчейн.

Ключові слова: інформаційні технології, міжнародний ринок, маркетингові стратегії, горизонти розвитку, ризики

Received to the editor 11 June 2020. 